\title{
Screening of endophytes from rubber trees (hevea brasiliensis) for biological control of Corticium salmonicolor
}

\author{
Nguyen Van Minh ${ }^{1}$, Mai Huu Phuc ${ }^{1}$, Duong Nhat Linh ${ }^{1}$, Tran Thi A Ni ${ }^{2}$, Tran Kien Duc ${ }^{3}$, \\ Nguyen Anh Nghia ${ }^{4}$ \\ ${ }^{1}$ Ho Chi Minh City Open University, Vietnam \\ ${ }^{2}$ Midoli co. ltd, Vietnam \\ ${ }^{3}$ University of Science, Vietnam National University Ho Chi Minh City, Vietnam \\ ${ }^{4}$ Rubber research institute of Vietnam, Vietnam \\ *Corresponding author: minh.nv@ ou.edu.vn
}

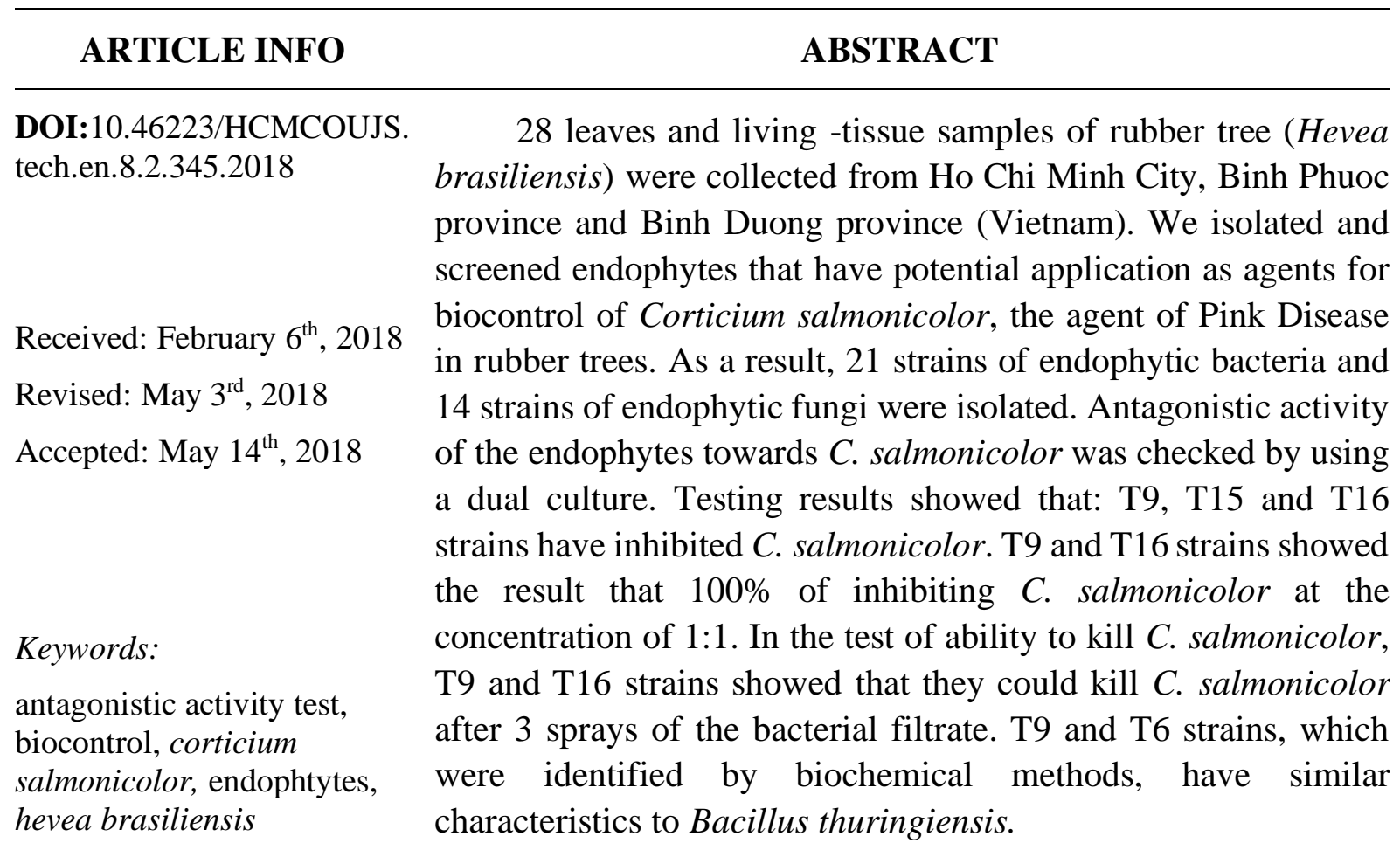

\section{Introduction}

The rubber tree (Hevea brasiliensis) is the native tree of South American in the Amazone rainforest. Although it was tamed from wild type recently, it is significantly important for the economy, commerce and society in many countries. However, the Rubber tree is usually attacked by pink disease (Corticium salmonicolor) that causes serious consequences. The pink disease can attack sapling and mature trees. Using too many chemical fungicides can lead to land degradation and insecticide resistance of insects. To cope with this problem, controlling disease by biological methods is catching more attention and some studies have recently been done (Narayanan \& Mydin, 2012). Endophytes are considered to be one of the most important target organisms that were isolated and screened for the bioproducts, using for the prevention of fungal diseases. Taking advantage of endogenous life characteristics in plant tissue should shorten the adaptation time of the biological product. It can create many antibiotics for fungal 
diseases, stimulates the growth of plants, and it does not affect the environment, public health (Khan, 2007; Strobel \& Daisy, 2003). The objective of this study was to find endophytes in rubber trees that have potential application as agents for biocontrol of Corticium salmonicolor.

\section{Materials and methods}

\subsection{Materials}

Endophytes were isolated from 28 samples of healthy rubber trees in $\mathrm{Cu}$ Chi DistrictHo Chi Minh City, Ben Cat District-Binh Duong Province, Chon Thanh and Dong Xoai District - Binh Phuoc Province. Corticium salmonicolor was provided from the Plant Protection Department of Rubber research institute of Vietnam.

\subsection{Methods}

\subsubsection{Isolation of endophytes}

Endophytes were isolated from leaves and living-tissues of healthy rubber trees, without the disease. The samples were isolated within 6 hours since they were collected. Tissues and leaves were washed under a strong jet of water, cutting into small section $2-4 \mathrm{~cm}$ for easy manipulation, surface disinfection of samples was done step by step, respectively: ethanol $70 \%$ (5 minutes), sodium hypochlorite $2 \%$ (5 minutes), ethanol $70 \%$ (30 seconds). Washing with sterile distilled water 5 times. Using sterilized equipment to cut/grind these samples and isolate on TSA (Trypticase Soy Agar), incubate at $37^{\circ} \mathrm{C}$ for several days to allow the growth of endophytic bacterial; on PDA (Potato Dextrose Agar) with Chloramphenicol $0.05 \%$ and sealed tightly paraffin, incubated at $27 \pm 2^{0} \mathrm{C}$ for from several days to 2 months to allow the growth of endophytic fungi (Arnold, Maynard, \& Gilbert, 2001; Gazis \& Chaverri, 2010; Khan, 2007).

\subsubsection{Resistance testing between endophytes and Corticium salmonicolor}

Using a dual testing method, Corticium salmonicolor and endophytes were cultured 3 $\mathrm{cm}$ apart on PDA (petri dish $90 \mathrm{~mm}$ ) at $27^{\circ} \mathrm{C}$ for 6 days. If endophytes have the ability to inhibit fungal disease, mycelium does not grow or grow weakly around the endophytes colonies. If endophytes have not the ability to inhibit the growth of the fungal disease, Corticium salmonicolor grows normally (Gong et al., 2006).

\section{concentration}

2.2.3. Identification of percentage of Corticium salmonicolor inhibition by

Bacteria were cultured in 50mL PD (Potato Dextrose Broth), shaking at $150 \mathrm{rpm}, 37^{\circ} \mathrm{C}$ for 48 hours. The culture medium was centrifuged at $9000 \mathrm{rpm}$ for 15 minutes at $4^{0} \mathrm{C}$. Then, filtered through membrane filter $0.2 \mu \mathrm{m}$. The culture medium was mixed with PGA $\left(45^{\circ} \mathrm{C}\right)$ at 5 ratios: 1:1, 1:2, 1:4, 1:8, 1:16 and pouring onto a petri dish $(90 \mathrm{~mm})$. Taking in $20 \mathrm{~mL}$ disease fungal solution $10^{6} \mathrm{CFU} / \mathrm{mL}$ pumped to the center area of the prepared Petri. Incubate at room temperature for 6 days and identify the percentage of inhibition according to the formula: $\mathrm{I}(\%)=(\mathrm{C}-\mathrm{E}) / \mathrm{C} \times 100 \%$, in it: $\mathrm{I}$ - the percentage of inhibition; $\mathrm{C}$ - diameter of fungi on the control Petri disk (mm); E - diameter of fungi on petri dish contain bacterial (mm); The bacteria are able to inhibit fungi at $\mathrm{I} \geq 20 \%$. The bacteria are not valuable in resistance fungi at $\mathrm{I}<20 \%$ (Chang, Chen, \& Jao, 2007). 

conditions

2.2.4. Identification of ability of Corticium salmonicolor killing under growth

The process of preparing bacterial culture is similar to the experiment percentage of inhibition Corticium salmonicolor. Bacterial culture was mixed with sterile distilled water at concentrations: $1,1: 2,1: 4,1: 8$ và 1:16. Spraying the bacterial concentrations onto the Pink Disease dish which were cultured on PDA for 4 days. The volume of bacterial to be sprayed is $2 \mathrm{~mL}$. The diameter of the fungi group was measured after 2 days of spraying. The spraying process was carried out 3 times, each time 2 days apart. After reading out the third result, the fungi which form the plates were sprayed bacteria were transplanted into PDA, incubated at 27 $\pm 20^{\circ} \mathrm{C}$ for 5 days, to test the viability of fungi. If the fungi do not grow, the bacteria are capable of destroying the fungi.

\subsubsection{Identification of endophytic strains}

The strains that strongly inhibited C.salmonicolor were identified by biochemical methods according to Cowan and Steel (Barrow \& Feitham, 1993).

\section{Results and discussion}

\subsection{Isolation of endophytes}

From 28 samples of foliage and sapwood of rubber tree (Hevea brasiliensis), we isolated 21 strains of endophytic bacterial and 14 strains of endophytic fungi.

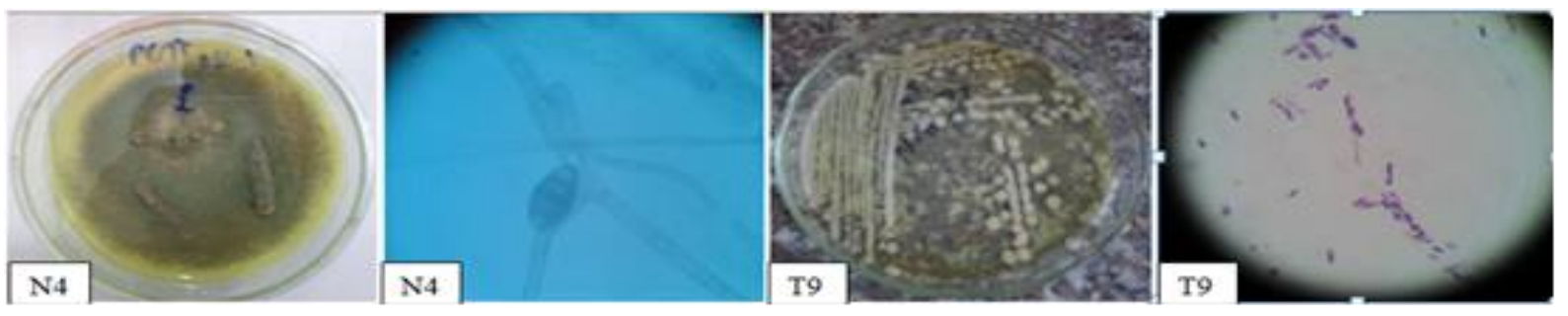

Figure 1. Macroscope (a) and microscope (b) endophytes fungi N4 Macroscope (c) and microscope (d) endophytes bacterial T9

\subsection{Result of Resistance testing between endophytes and Corticium salmonicolor}

After 6 days of testing, among 21 of strains endophytic bacterial and 14 strains of endophytic fungi, T9, T15, T16 endophytic bacterial strains can resist Corticium salmonicolor. T9 and T16 showed the strongest resistance among them (Figure 2a). The remaining strains have no resistance ability. The T9 and T16 were used for subsequent testings. Studies by Philip (2004) showed a similar result that bacteria isolated from rubber tree can resist Corticium salmonicolor.

\subsection{Result of identification of percentage of Corticium salmonicolor inhibition by concentration}

After 6 days of testing, percentage of Corticium salmonicolor inhibition by concentration $1: 1,1: 2,1: 4,1: 8$ and 1:16 of T9 strain were $100 \pm 0.00 \%$ (Figure 2b), $98.89 \pm$ $0.56 \%, 93.77 \pm 2.12 \%, 72.44 \pm 0.77 \%, 45.8 \pm 82.41 \%$, respectively; and that of $\mathrm{T} 16$ strain were 
$100 \pm 0.00 \%, 76.66 \pm 5.09 \%, 67.0 \pm 2.45 \%, 55.55 \pm 3.37 \%$ and $43.67 \pm 4.09 \%$, respectively. This testing showed that concentration of bacteria decline, the ability to inhibit fungi also decline.

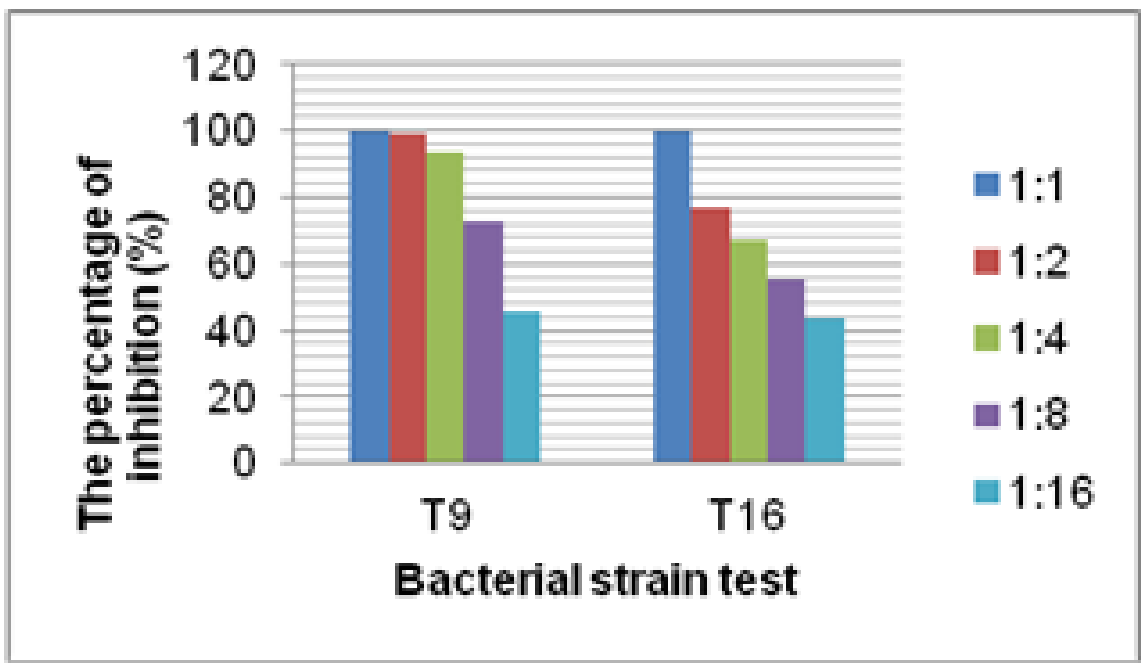

Figure 2. The graph show the percentage of inhibition C. salmonicolor of the strains in the concentrations
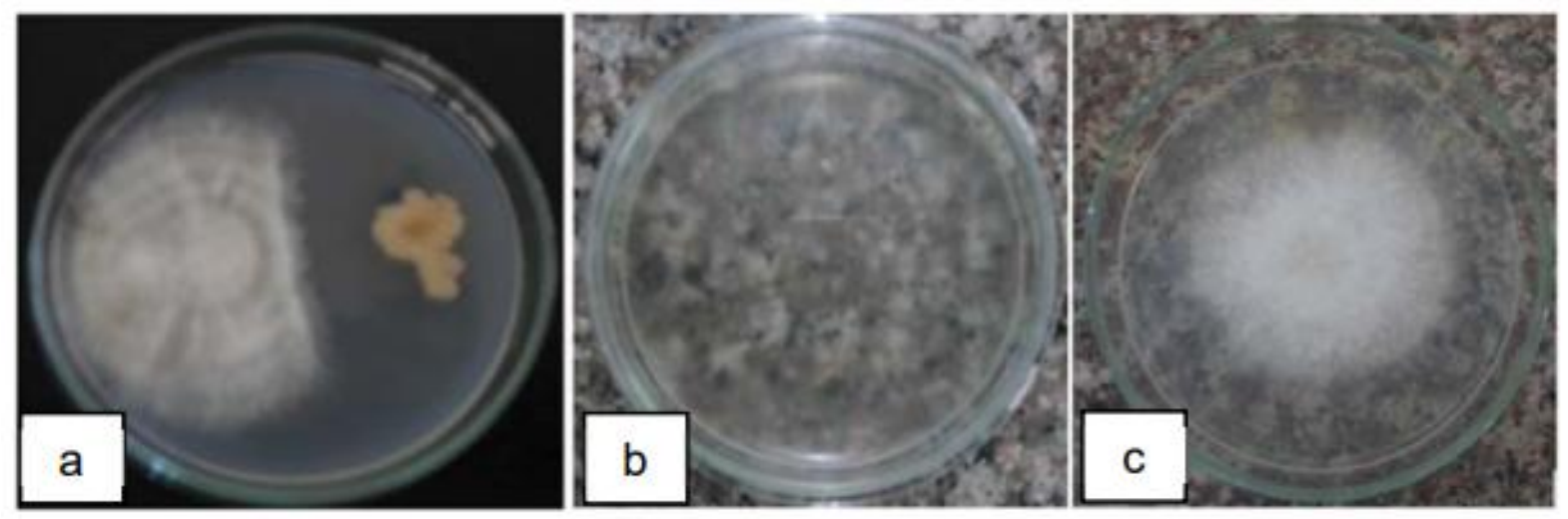

Figure 3. (a) - Ability of endophytic bacterial T9 resistance to C. salmonicolor; (b) Percentage of inhibition C. salmonicolor of T9 in 1:1 concentration. (c) - Control sample.

\subsection{The result of spraying endophytic culture fluid to $C$. salmonicolor}

After 10 days of testing, combining observation and measurement of fungal growth diameter, we collected the result. At the test of both T9 strain and T16 strain with 1 and 1:2 concentration, mycelia were dry and no signal of growth. The remaining concentrations 1: 4, 1: $8,1: 16$ showed a signal of mycelial growth but limited (Table 1,2). 


\section{Table 1}

The results of spraying endophytic T9 strain to C. salmonicolor

\begin{tabular}{|c|c|c|c|c|c|c|c|}
\hline \multirow{2}{*}{$\begin{array}{c}\text { Dilute } \\
\text { Concentration }\end{array}$} & \multicolumn{7}{|c|}{ Result of fungal diameter (mm) } \\
\cline { 2 - 8 } & $\begin{array}{c}\text { Before } \\
\left(4^{\text {th }} \text { day }\right)\end{array}$ & $\begin{array}{c}\text { First } \\
\left(6^{\text {th }} \text { day }\right)\end{array}$ & $\begin{array}{c}\text { Growth } \\
\text { diameter }\end{array}$ & $\begin{array}{c}\text { Second } \\
\left(\mathbf{8}^{\text {th }} \text { day }\right)\end{array}$ & $\begin{array}{c}\text { Growth } \\
\text { diameter }\end{array}$ & $\begin{array}{c}\text { Third } \\
\left(\mathbf{1 0}^{\text {th }} \text { day }\right)\end{array}$ & $\begin{array}{c}\text { Growth } \\
\text { diameter }\end{array}$ \\
\hline $1: 1$ & $52,33 \pm 1,45$ & $54,33 \pm 2,19$ & $1,00 \pm 0,74^{\text {d }}$ & $55,33 \pm 1,20$ & $1,00 \pm 0,46^{\mathrm{c}}$ & $55,67 \pm 1,33$ & $0,00 \pm 0,00^{\mathrm{b}}$ \\
\hline $1: 2$ & $57,67 \pm 2,33$ & $64,33 \pm 2,72$ & $6,66 \pm 0,39^{\mathrm{c}}$ & $65,00 \pm 2,51$ & $0,67 \pm 0,21^{\mathrm{c}}$ & $65,33 \pm 2,67$ & $0,00 \pm 0,00^{\mathrm{b}}$ \\
\hline $1: 4$ & $54,00 \pm 1,00$ & $65,00 \pm 0,57$ & $11,00 \pm 0,43^{\mathrm{b}}$ & $66,00 \pm 0,57$ & $1,00 \pm 0,00^{\mathrm{c}}$ & $66,33 \pm 0,57$ & $0,33 \pm 0,00^{\mathrm{b}}$ \\
\hline $1: 8$ & $51,67 \pm 0,33$ & $63,00 \pm 0,58$ & $11,33 \pm 0,25^{\mathrm{b}}$ & $65,67 \pm 0,67$ & $2,67 \pm 0,09^{\mathrm{b}}$ & $66,00 \pm 0,57$ & $0,33 \pm 0,10^{\mathrm{b}}$ \\
\hline $1: 16$ & $53,67 \pm 2,33$ & $65,00 \pm 1,00$ & $11,33 \pm 1,33^{\mathrm{b}}$ & $67,00 \pm 0,10$ & $2,00 \pm 0,90^{\mathrm{b}}$ & $68,33 \pm 0,67$ & $1,33 \pm 0,57^{\mathrm{b}}$ \\
\hline Control & $50,00 \pm 2,89$ & $63,00 \pm 2,08$ & $13,00 \pm 0,81^{\mathrm{a}}$ & $66,67 \pm 1,08$ & $3,67 \pm 0,73^{\mathrm{a}}$ & $76,00 \pm 4,70$ & $9,33 \pm 3,62^{\mathrm{a}}$ \\
\hline
\end{tabular}

Source: The researcher's data analysis

\section{Table 2}

The results of spraying endophytic T16 strain to C. salmonicolor

\begin{tabular}{|c|c|c|c|c|c|c|c|}
\hline \multirow[b]{2}{*}{$\begin{array}{c}\text { Dilute } \\
\text { concentration }\end{array}$} & \multicolumn{7}{|c|}{ Result of fungi diameter (mm) } \\
\hline & $\begin{array}{c}\text { Before } \\
\text { spraying } \\
\left(4^{\text {th }} \text { day) }\right.\end{array}$ & $\begin{array}{c}\text { First } \\
\left(6^{\text {th }} \text { day }\right)\end{array}$ & $\begin{array}{l}\text { Growth } \\
\text { diameter }\end{array}$ & $\begin{array}{l}\text { Second } \\
\left(8^{\text {th }} \text { day }\right)\end{array}$ & $\begin{array}{c}\text { Growth } \\
\text { diameter }\end{array}$ & $\begin{array}{c}\text { Third } \\
\left(10^{\text {th }} \text { day }\right)\end{array}$ & $\begin{array}{c}\text { Growth } \\
\text { diameter }\end{array}$ \\
\hline $1: 1$ & $52,33 \pm 2,33$ & $60,00 \pm 1,52$ & $7,67 \pm 0,81^{\mathrm{c}}$ & $60,67 \pm 1,20$ & $0,67 \pm 0,32^{\mathrm{c}}$ & $62,00 \pm 1,52$ & $0,00 \pm 0,00^{\mathrm{b}}$ \\
\hline $1: 2$ & $54,67 \pm 1,45$ & $60,00 \pm 1,52$ & $5,33 \pm 0,07^{\mathrm{d}}$ & $61,00 \pm 2,00$ & $1,00 \pm 0,48^{\mathrm{bc}}$ & $61,00 \pm 2,00$ & $0,00 \pm 0,00^{\mathrm{b}}$ \\
\hline 1:4 & $48,00 \pm 3,05$ & $55,67 \pm 3,84$ & $7,67 \pm 0,79^{c}$ & $56,67 \pm 3,33$ & $1,00 \pm 0,51^{\mathrm{bc}}$ & $57,00 \pm 3,51$ & $0,33 \pm 0,18^{\mathrm{b}}$ \\
\hline $1: 8$ & $53,33 \pm 1,33$ & $64,33 \pm 1,45$ & $11,00 \pm 0,12^{\mathrm{b}}$ & $66,00 \pm 1,52$ & $1,67 \pm 0,07^{\mathrm{b}}$ & $67,00 \pm 2,00$ & $1,00 \pm 0,48^{\mathrm{b}}$ \\
\hline $1: 16$ & $53,00 \pm 4,04$ & $63,67 \pm 1,86$ & $10,67 \pm 2,18^{b}$ & $66,67 \pm 2,02$ & $3,00 \pm 0,16^{\mathrm{a}}$ & $68,67 \pm 1,86$ & $2,00 \pm 0,16^{\mathrm{b}}$ \\
\hline Control & $50,00 \pm 2,89$ & $63,00 \pm 2,08$ & $13,00 \pm 0,81^{\mathrm{a}}$ & $66,67 \pm 1,08$ & $3,67 \pm 0,73^{\mathrm{a}}$ & $76,00 \pm 4,70$ & $9,33 \pm 3,62^{a}$ \\
\hline
\end{tabular}

Notes: Table 1, 2, in the same column, the average values following the same letter are not different at $95 \%$.

Source: The researcher's data analysis

Examining the survival of fungal disease, results obtained as follows: plates have spray T9 and T16 strain at 1:1 and 1:2 concentration, mycelium did not grow, the plate control has growth fungi with $63,33 \pm 1,33 \mathrm{~mm}$ diameter. From this result, we can conclude: at 1:1 and 1:2 
concentration, T9 and T16 can kill $C$. salmonicolor. If the concentration of bacteria declines $(1: 4,1: 8,1: 16)$, the ability to inhibit fungi also declines.

\subsection{Result of identification of T9 and T16 strain}

With the identification according to Cowan and Steel, the T9 and T16 strain have characteristics similar to Bacillus thuringiensis. Bacillus thuringiensis can resist diseased fungi.

\section{Conclusion}

With the experimental results above, we isolated 21 endophytic bacterial strains and 14 endophytic fungal strains. T9 and T16 strains can inhibit Corticium salmonicolor 100\% at concentration 1:1 and kill fungi at concentration 1:1 and 1:2 after spraying 3 times. The identification result showed that 2 strains T9 and T16 have characteristics similar to Bacillus thuringiensis.

\section{ACKNOWLEDGEMENTS}

This work was funded by Ho Chi Minh Open University.

\section{References}

Ahmad, I. A. F., \& Khan, M. S. (2006). Screening of free-living rhizospheric bacteria for their multiple plant growth promoting activities. Microbiological Research, 163(2), 173-181.

Alfiereri, S. A. (1968). Limb blight disease caused by Corticium samonicolor B. \& Br. Plant Pathology Circular. Retrieved December 1, 2020, from https://www.yumpu.com/en/document/read/13292463/limb-blight-disease-caused-bycorticium-salmonicolor-b-florida-

Arnold, A. E., Maynard, Z., \& Gilbert, G. S. (2001). Fungal endophytes in dicotyledonous neotropical trees: Patterns of abundance and diversity. Mycological Research, 105(12), 1502-1507.

Bandara, W. M. M. S., Seneviratne, G., \& Koolasooriya, S. A. (2006). Interactions among endophytic bacteria and fungi: Effects and potentials. Journal of Biosciences, 31(5), 645650 .

Barrow, G. I., \& Feitham, R. K. A. (1993). Cowan, Steel's manual for the identification of medical bacteria. New York, NY: Cambridge University Press.

Chang, W. T., Chen, Y. C., \& Jao, C. L. (2007). Antifungal activity and enhancement of plant growtn by Bacillus cereus grown on shellfish chitin wastes. ScienceDirect, Bioresource Technology, 98(6), 1224-1230.

Gazis, R., \& Chaverri, P. (2010). Diversity of fungal endophytes in leaves and stems of wild rubber trees (Hevea brasiliensis) in Peru. Fungal Ecology, 3(3), 240-254.

Gazis, R., Miadlikowska, J., Lutzoni, F., Arnold, A. E., \& Chaverri, P. (2012). Culture-based study of endophytes associated with rubber trees in Peru reveals a new class of 
Pezizomycotina: Xylonomycetes. Molecular Phylogenetics and Evolution, 65(1), 294304.

Gong, M., Wang, J. D., Zhang, J., Yang, H., Lu, X. F., Pei, Y., \& Cheng, J. Q. (2006). Study of the antifungal ability of bacillus subtilis strain PY-1 in vitro and identification of its antifungal substance (Iturin A). Acta Biochimica et Biophysica Sinica, 38(4), 233-240.

Khan, R. (2007). Isolation, identification and cultivation of endophytic fungi from medicinal plants for the production and characterization of bioactive fugal metabolites (Unpublished master's thesis). Department of Microbiology, University of Karachi, Pakistan.

MacFaddin, J. F. (2000). Biochemical test for identification of medical bacteria. New York, NY: Lippincott Williams \& Wilkins.

Narayanan, C., \& Mydin, K. K. (2012). Breeding for disease resistance in hevea spp. status, potential threats, and possible strategies. In General technical report PSW-GTR-240. Albany, NY: U.S. Department of Agriculture, Forest Service, Pacific Southwest Research Station.

Philip, M. (2004). Association of microflora with rubber (Hevea brasiliensis) and their beneficial roles (Unpublished master's thesis). Plant Pathology Division, Rubber Research Institute of India, India

Reyes-Ramírez, A., Escudero-Abarca, B. I., Aguilar-Uscanga, G., Hayward-Jones, P. M., \& Eleazarbaraboza-Corona, J. (2004). Antifungal activity of Bacillus thuringiensis Chitinase and its potential for the biocontrol of Phytopathogenic fungi in soybean seeds. Journal of Food Science, 69(5), M131-M134.

Ryan, R. P., Germaine, K., Franks, A., Ryan D. J., \& Dowling, D. N. (2007). Bacterial endophytes: Recent developments andapplications. FEMS Microbiolgy Letters, 278(1), $1-9$.

Strobel, G. A., \& Daisy, B. (2003). Bioprospecting for microbial endophytes and their natural products. Microbiology and Molecular Biology Reviews, 67(4), 491-502. 